\title{
Effect of integrated use of phosphorus, biofertilizers and organic manures on soil available nutrient status and yield of greengram (Vigna radiata $\mathrm{L}$. )
}

G. Bhavya, K. Chandra Shaker, G. Jayasree and M. Malla Reddy

Received : 02.02.2018; Revised : 06.05.2018; Accepted : 20.05.2018

MEMBERS OF RESEARCH FORUM:

Corresponding author : G. Bhavya, Department of Soil Science and Agricultural Chemistry, Agricultural College (PJTSAU), Poalsa, Jagtial, Hyderabad (Telangana) India

\section{Co-authors :}

K. Chandra Shaker, G. Jayasree and M. Malla Reddy, Department of Soil Science and Agricultural Chemistry, Agricultural College (PJTSAU), Poalsa, Jagtial, Hyderabad (Telangana) India

\begin{abstract}
Summary
The effect of inorganic phosphorus, phosphate solubilising bacteria and vermicompost on yield of greengram and available nutrient status was studied during Kharif 2016 at Agricultural College, Polasa, Jagtial, Telangana state, India. The experiment was conducted with three levels of phosphorus $(0,75$ and $100 \%$ RDP), phosphate solubilising bacteria ( 0 and $2 \mathrm{~kg}$ $\left.\mathrm{ha}^{-1}\right)$ and vermicompost $\left(0\right.$ and $\left.5 \mathrm{tha}^{-1}\right)$. The results revealed that grain and haulm yields were increased with increasing inorganic P levels and when the crop was supplemented with PSB and vermicompost. Significantly higher grain $\left(1033.33 \mathrm{~kg} \mathrm{ha}^{-1}\right)$ and haulm yield (1625.66 kg $\mathrm{ha}^{-1}$ ) were recorded when the crop was integrated with $100 \%$ RDP along with PSB and vermicompost. Results also indicated that there was a significant build-up in available N, P, K and $\mathrm{S}$ status with increasing inorganic $\mathrm{P}$ levels, seed inoculation with PSB and vermicompost application. Thus, it shows positive influence by the application of phosphatic fertilizers, organic manures and biofertilizers.
\end{abstract}

Key words : Integrated phosphorus management, Green gram, Yield, Phosphorus levels, PSB, Available nutrients

How to cite this article : Bhavya, G., Chandra Shaker, K., Jayasree, G. and Reddy, M. Malla (2018). Effect of integrated use of phosphorus, biofertilizers and organic manures on soil available nutrient status and yield of greengram (Vigna radiata L.). Asian J. Soil Sci., 13 (1) : 45-49 : DOI : 10.15740/HAS/AJSS/ 13.1/45-49. Copyright@ 2018: Hind Agri-Horticultural Society. 